\title{
Drinking water treatment residuals as an amendment to alkaline soils: Effects on the growth of corn and phosphorus extractability
}

\author{
${ }^{1 *}$ A. M. Mahdy; ${ }^{1}$ E. A. Elkhatib; ${ }^{2}$ N. O. Fathi \\ ${ }^{1}$ Department of Soil and Water, College of Agriculture, Alexandria University, Alexandria, Egypt \\ ${ }^{2}$ Salinity and Alkalinity Soils Research Laboratory, Ministry of Agriculture, Cairo, Egypt \\ Received 22 April 2007; revised 22 June 2007; accepted 12 August 2007; available online 1 September
}

\begin{abstract}
Drinking water treatment residuals (alum) are waste products of water purification that have potential for environmental remediation as a soil amendment and a potential plant growth medium. In this study, the influence of added Drinking water treatment residuals on the extractability and availability of phosphorus to plants; determination of the agronomic rate of alum to different agricultural soils and evaluation of the alum as ameliorating material for soil conditions and plant growth were investigated. In all studied soils, increasing drinking water treatment residuals rate up to $30 \mathrm{~g} / \mathrm{kg}$ significantly increased dry matter yield. Application of 10, 20 and $30 \mathrm{~g} / \mathrm{kg}$ alum significantly increased plant $\mathrm{P}$ concentrations in the plant materials (shoots and roots) taken from clay, sandy and calcareous soils. Further increase in alum application rate has resulted in negative significant impact on plants $\mathrm{P}$ concentration, especially in clay and calcareous soils, but in sandy soils the increase in phosphorusconcentration extended to $40 \mathrm{~g} / \mathrm{kg}$ alum rate. Application of alum at rates up to $30 \mathrm{~g} / \mathrm{kg}$ significantly increased available phosphorus concentrations of the three studied soils. However, application of alum at a rate of $40 \mathrm{~g} / \mathrm{kg}$ to clay and calcareous soils significantly decreased available phosphorus concentrations. Combined analyses of all soils and alum rates studied clearly indicated significant relationship between available phosphorus concentration and phosphorus uptake $(\mathrm{r}=0.87, \mathrm{P}<0.001)$. Based on our experiment results, the rate of $30 \mathrm{~g} / \mathrm{kg}$ is considered the best application rate of alum because of its positive effects on plant dry matter. Our study clearly demonstrates that alum has potential as a soil amendment to increase plant growth; however, more research is needed to determine beneficial and / or detrimental aspects of this practice under field conditions.
\end{abstract}

Key words: Water treatment residuals, phosphorus, extractability, plant, yield

\section{INTRODUCTION}

Aluminum sulphate (alum) is a common chemical, fast and cost effective method for water purification and improving water quality (Klapper, 1991; Barroin, 1999). Hypolimnetic application of solid alum may reduce phosphorus levels, due to the ability of its hydroxide $\left[\mathrm{A} 1(\mathrm{OH})_{3}\right]$ to adsorb phosphorus at $\mathrm{pH}$ of 5.20-8.80 (Mortell and Motekaitis, 1989), remove colloidal organic matter and therefore increase water transparency (Francko and Heath, 1981; Jiang and Graham, 1998) even under anoxic conditions. Drinking water treatment residuals (DWTR) are waste products that have potential for environmental remediation as a soil amendment (Makris and Harris, 2005) and a potential plant growth medium (Skene et al., 1995) because its high content of organic matter ( 0.85 to 6.5 $\%)$. Changes in soil water retention have been

ه*Corresponding Author Email: amahdy73@yahoo.com Tel./Fax: +23 5904684 documented after DWTR land application. Bugbee and Frink (1985) and Rengasamy, et al., (1980) observed soil moisture retention and aeration improvements after DWTR additions. Only a few studies have reported the consequences of land application of DWTR with respect to plant growth and environmental impact. Addition of DWTR at rates as low as $0.89 \mathrm{gk} / \mathrm{gresulted}$ in an increase in the growth of maize (Zea mays L.) (Bugbee and Frink, 1985). Tissue analysis of tomato shoots (Elliott and Singer, 1988) and lettuce (Bugbee and Frink, 1985) grown in potting media amended with DWTR had significantly lower phosphorus levels. Our study objectives were to (i) evaluate the DWTR additions on plant growth; (ii) determine the influence of added DWTR on the extractability and availability of phosphorus to plants; and (iii) determine the agronomic rate of DWTR to different alkaline agricultural soils. 


\section{MATERIALS AND METHODS}

Characterization of soils and drinking water treatment residuals (DWTR)

Three soils with different properties (clay, sandy and calcareous) were selected for the study and sampled (0-15 cm depth) from three different locations. Sub-samples of the air-dried soils were ground to pass a 2-mm sieve prior to the following chemical analysis:$\mathrm{pH}$ and electrical conductivity (EC) as well as soluble cations and anions: soil-paste extract (Richard, 1954); organic matter: dichromate oxidation (Nelson and Sommers, 1982); cation exchange capacity (CEC): IM NaOAC (Rhoades, 1982); particle size: the hydrometer method (Day, 1965); calcium carbonate: by means of a calcimeter (Nelson, 1982); total nitrogen: Kjeldah/ digestion method (Bremner and Mulvaney, 1982); available phosphorus: $0.5 \mathrm{M} \mathrm{NaHCO}_{3}$ test (Olsen and Sommers, 1982); available nitrogen: $2 \mathrm{M} \mathrm{KCl}$ (Bremner and Mulvaney, 1982); available potassium: $1 \mathrm{~N}$ ammonium acetate (Knudsen and Peterson,1982); extractable aluminum: $1 \mathrm{M} \mathrm{KCl}$ colorimetrically by 8hydroxy quinoline-butyl acetate (Bloom, et al., 1978). Selected properties of the three soils are summarized in Table 1. The DWTR was obtained from the drinking water treatment plant in Kafr El-dawar, El-bohera Governorate, Egypt. The DWTR particles were allowed to air-dry and were subsequently passed through a $1 \mathrm{~mm}$ sieve prior to their use in any experiment (Makris and Haris,2005). The pH of
DWTR-water: suspension 1:2.5; salinity: in DWTRwater extract 1:2; cation exchange capacity of DWTR: sodium saturation (Rhoades, 1982); organic matter content: dichromate oxidation (Nelson and Sommers, 1982); total Al of DWTR: the acid ammonium oxalate method (Ross and Wang, 1993); extractable Aluminum: $1 \mathrm{M} \mathrm{KCl}$; total metals: according to Ure, (1995); water holding capacity: according to Skene, et al.,(1995). Selected chemical and physical properties of DWTR are summarized in Table 1.

\section{Incubation experiment}

To ensure amendment-soils equilibria, incubation experiment was conducted. Five DWTR rates $(0,10$, 20,30 and $40 \mathrm{~g} / \mathrm{kg}$ on an oven dry basis) were applied to each soil (calcareous, sandy and clay soils) and thoroughly mixed. Soil for each treatment was transferred to a large plastic bowl. Two- thirds of the water required to obtain field capacity (F.C) was initially added to the soil with a water dispenser and mixed thoroughly to form a uniform soil-DWTR-water mixture. Treated soil mixture were then transferred to a plastic pot (2 kg/pot) and brought to field capacity. The Moisture content of the treated soil mixture was kept constant during incubation by calculating the field capacity and periodically weighing the pots and adding deionized water to compensate for evaporative loss. Pots were covered with perforated plastic cover and incubated at $25^{\circ} \mathrm{C}$ for 60 days.

Table 1: Some physical and chemical characteristics of studied soils and DWTR

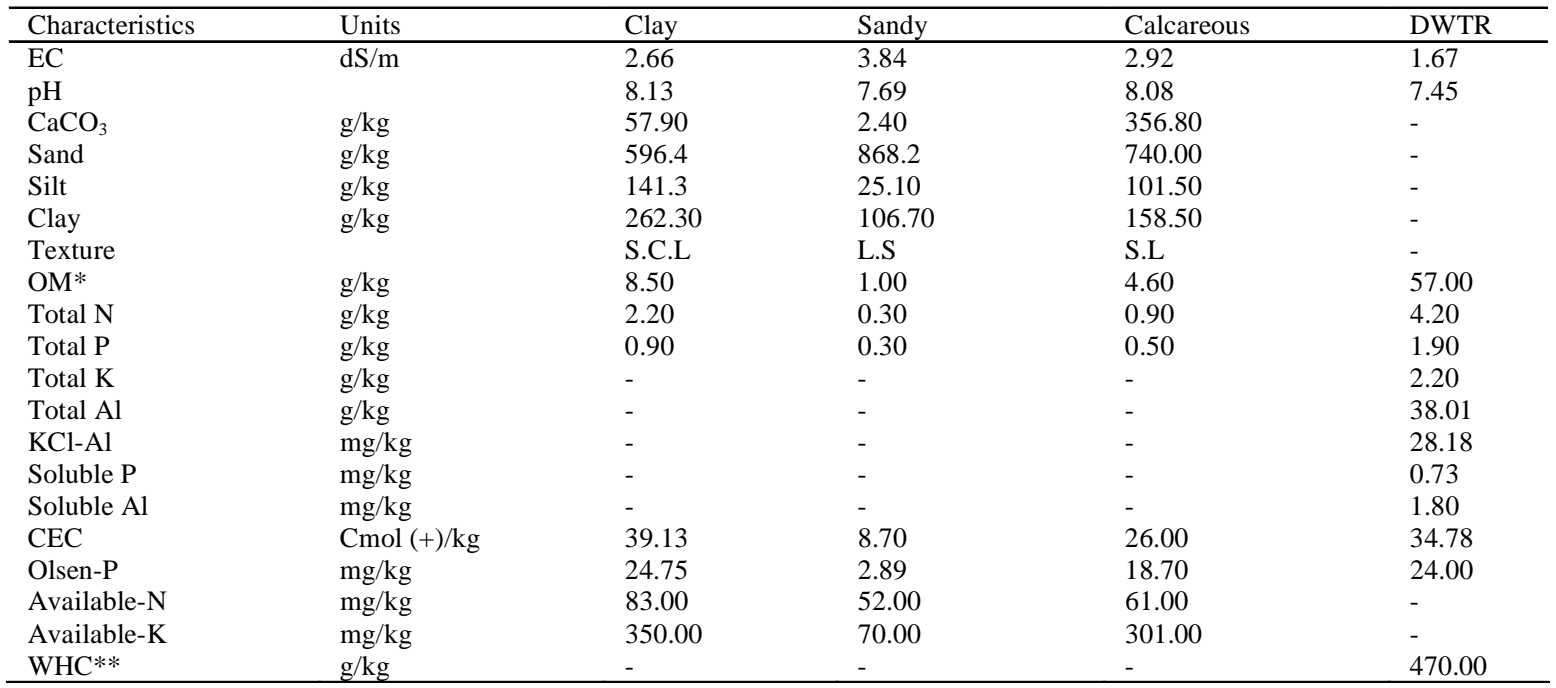

* OM: organic matter

** WHC: water holding capacity 
After the incubation period, corresponding soil samples were air-dried, crushed to pass a $2 \mathrm{~mm}$ sieve and stored for analysis.

\section{Greenhouse experiment}

After the incubation period, corn seeds (Zea mays) were sown in the plastic pots filled with $2 \mathrm{~kg}$ of the three studied soils (calcareous, sandy and clay soils) in the summer of year 2006. No fertilizers were added because the soil testing indicated sufficient amounts of nitrogen, potassium and phosphorus in the three amended soils. The seedlings were thinned to 4 seedlings per pot and deionized water was added to bring the soil moisture to $70 \%$ of field capacity during the days of com growth. The experiment was arranged in completely randomized with four replicates. Plants were harvested after 105 days of growth in the tested soils. No nutritional disorders were observed during the period of growth.

\section{Phosphorus extraction}

The sodium bicarbonate $(0.5 \mathrm{M})$ extracting solution was used to extract available phosphorus from soils treated with and without DWTR before cultivation (Olsen and Sommers, 1982).

\section{Plant and soil analysis}

Plant shoots and roots were harvested separately, and immediately after harvest shoots and roots were triple rinsed in deionized water to remove any adhering particles. Plants were oven dried at $65^{\circ} \mathrm{C}$ for $48 \mathrm{~h}$ and dry matter yield was recorded. Plant tissues were ground in a stainless steel mill. Subsamples of ground plant material were dry-ashed in a muffle furnace at $450{ }^{\circ} \mathrm{C}$ for $6 \mathrm{~h}$. Ash was dissolved in $5 \mathrm{ml}$ of $\mathrm{HNO}_{3}(1: 1)$, diluted to a constant volume with distilled water and analyzed colorimetrically for phosphorus (Jones, 2001). Following plant harvest, representative soil samples were collected from each pot. Soil samples were air-dried and crushed before analysis. Sodium bicarbonate $(0.5 \mathrm{M})$ extractable phosphorus was determined using the method of Olsen and Sommers, (1982).

\section{Statistical analysis}

Statistical analysis were performed using Statistical Analysis System (SAS Institute, 1994). Analysis of variance (ANOVA) techniques were used to determine treatment effects and check for interaction. The least significant difference method was used to separate treatment means. Regression analysis was employed to determine the relationships between available $\mathrm{P}$ concentration in soils and $\mathrm{P}$ concentration in plants.

\section{RESULTS}

Characterization of soils and drinking water treatment residuals (DWTR)

Soils tested in this study differ in their chemical and physical characteristics (Table 1). The sandy soil is coarse textured with low contents of calcium carbonate and organic matter and is classified as (Typic Torripsamments). The clay soil contains higher amounts of organic matter, CEC, and calcium carbonate than sandy soil, and classified as (Typic Torrifluvents) according to Abdel-Kader and Abdel-Hamid, (1974). The calcareous soil is classified as (Typic Calciorthids). The content of calcium carbonate in calcareous soil samples is higher than clay and sandy soil samples. The available phosphorus content in clay soil is 10 times higher than that of the sandy soil. Analysis of drinking water treatment residuals (DWTR) is presented in Table (1).In brief, total $\mathrm{Al}(38.01 \mathrm{~g} / \mathrm{kg})$ and organic matter content $(57.00 \mathrm{~g} / \mathrm{kg})$ were high and approximately typical of Al-DWTR produced nationally. The DWTR was slightly alkaline (7.45) within the adequate typical range for plant growth (5-8) (Bohn et al., 1985). The electrical conductivity of DWTR is well below the $4 \mathrm{dSm}^{-1}$ and the CEC of the DWTR indicates its ability to supply cationic nutrients for plant growth. In addition, the available P content $(24.00 \mathrm{mg} / \mathrm{kg}$ ) was high. The water holding capacity of DWTR is very well (47\%). So the DWTR is a good ameliorating agent to soil properties and a potential plant growth medium (Skene et al., 1995).

\section{Dry matter production of corn}

The total dry matter and dry matter partitioning of corn plants grown in the three soils as influenced by DWTR application rates are shown in Table 2. In all studied soils, increasing DWTR rate up to $30 \mathrm{gk} / \mathrm{g}$ significantly increased dry matter yield. The dry matter production of corn in the control treatment for the three soils were in the order clay $>$ calcareous $>$ sandy. Soil main effects were significant $(\mathrm{p}<0.001)$ for total dry matter yield, root dry matter and shoot dry matter yield (Table $2)$. DWTR main effects were also significant $(p<0.001)$ for total, shoot and root dry matter yield. 
Drinking water treatment residuals as an amendment to alkaline soils effects on the growth...

Table 2: Total dry matter and dry matter partitioning of corn plants grown in the three soils as influenced by DWTR application rate

\begin{tabular}{|c|c|c|c|}
\hline \multirow{2}{*}{ DWTR rate } & \multirow{2}{*}{$\begin{array}{c}\text { Total dry } \\
\text { matter }\end{array}$} & \multicolumn{2}{|c|}{ Dry matter partitioning } \\
\hline & & Roots & Shoots \\
\hline $\mathrm{g} / \mathrm{kg}$ & $\begin{array}{l}\text { g/pot } \\
\text { Cla }\end{array}$ & \multicolumn{2}{|c|}{ \% of total dry matter } \\
\hline 0 & 38.30 & 27.31 & 72.68 \\
\hline 10 & 48.96 & 21.93 & 78.06 \\
\hline 20 & 79.66 & 19.73 & 80.26 \\
\hline 30 & 86.16 & 20.33 & 79.66 \\
\hline 40 & 54.09 & 22.72 & 77.27 \\
\hline Mean & 61.43 & 22.40 & 77.59 \\
\hline $\operatorname{LSD}_{0.05}$ & 2.58 & 0.12 & 0.10 \\
\hline \multicolumn{4}{|c|}{ Sandy soil } \\
\hline 0 & 5.26 & 32.51 & 67.49 \\
\hline 10 & 7.06 & 31.58 & 68.42 \\
\hline 20 & 10.32 & 32.65 & 67.35 \\
\hline 30 & 14.39 & 38.29 & 61.71 \\
\hline 40 & 15.80 & 42.03 & 57.97 \\
\hline Mean & 10.57 & 35.41 & 64.59 \\
\hline $\operatorname{LSD}_{0.05}$ & 0.92 & 0.06 & 0.06 \\
\hline \multicolumn{4}{|c|}{ Calcareous } \\
\hline 0 & 8.90 & 28.31 & 71.69 \\
\hline 10 & 11.81 & 32.93 & 67.07 \\
\hline 20 & 14.31 & 30.05 & 69.95 \\
\hline 30 & 17.90 & 35.15 & 68.85 \\
\hline 40 & 17.24 & 20.17 & 79.83 \\
\hline Mean & 14.03 & 29.32 & 71.48 \\
\hline $\mathrm{LSD}_{0.05}$ & 0.47 & 0.04 & 0.03 \\
\hline Analysis of & \multicolumn{3}{|c|}{$F$-test } \\
\hline variance & TDM & RDM & SDM \\
\hline Soil & $* * *$ & $* * *$ & $* * *$ \\
\hline Rate & $* * *$ & $* * *$ & $* * *$ \\
\hline Rate $\mathrm{X}$ soil & $* * *$ & $* * *$ & $* * *$ \\
\hline
\end{tabular}

Similarly, a significant rate of DWTR x soil interaction was observed for total, shoot and root dry matter yield (Table 2). Drinking water treatment residual application to soils has raised issues about possible changes in soils' water holding capacity. The water holding capacity of the three studied soils as affected by DWTR application rates are shown in Table 3.The data indicated that as the DWTR amendments rate increased the water holding capacity increased for the three soils. The changes in the water holding capacity as a function of amendment rate were more pronounced in the clay soils versus sandy and calcareous soils.

\section{Phosphorus concentration in corn plants}

Generally, phosphorus concentration tends to be accumulated in the order shoots rather than roots of corn plants grown in DWTR treated soils (Fig. 1). Application of 10, 20 and 30 gk/g DWTR significantly increased plant phosphorus concentrations in the plant materials (shoots and roots) taken from the three soils (Fig. 1). Further increase in DWTR application rate has resulted in negative significant impact on plants phosphorus concentration, especially in clay and calcareous soils, but in sandy soils the increase in phosphorus concentration extended to $40 \mathrm{gk} / \mathrm{g}$ DWTR rate.

Phosphorus extractability before cultivation and after harvest of corn

The available phosphorus concentrations in the three studied soils as influenced by drinking water treatment residuals before cultivation and after harvest of corn plants are presented in Table 4. Soil type, DWTR rate, and soil $x$ rate interaction significantly affected available phosphorus concentration (Table 4). Application of DWTR at rates up to $30 \mathrm{~g} / \mathrm{kg}$ significantly increased available phosphorus concentrations of the three studied soils.

Table 3: Water Holding Capacity (WHC) of the three soils as influenced by DWTR application rate

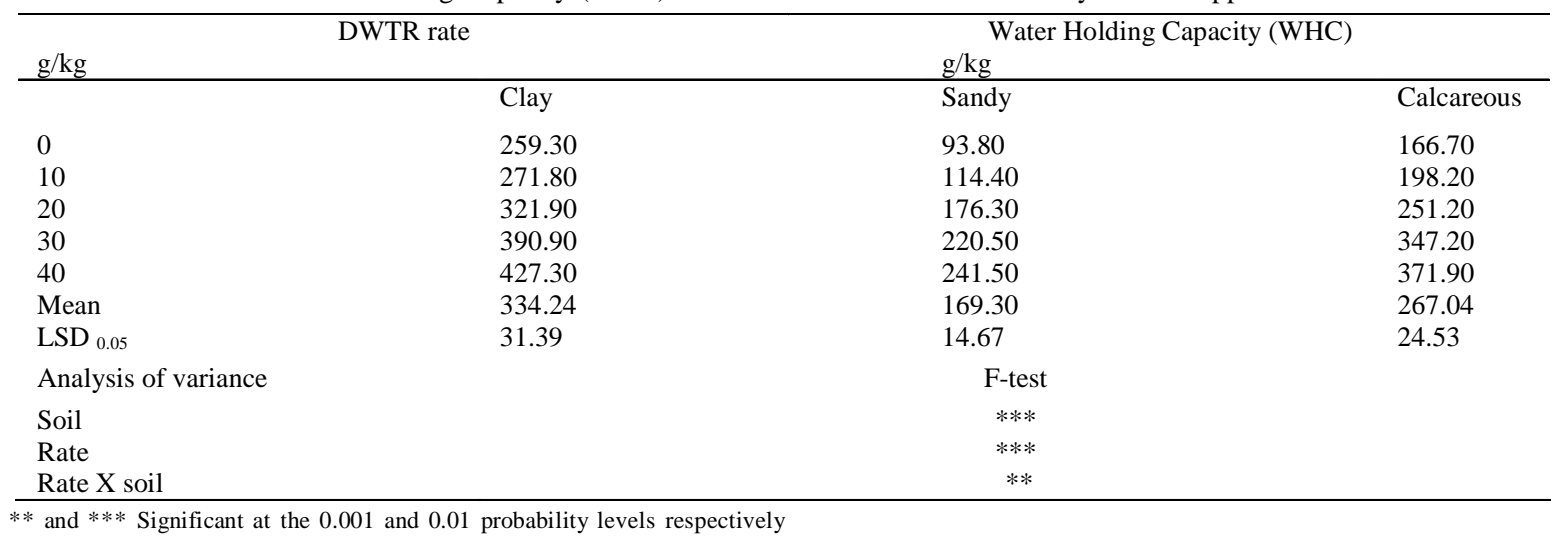


Int. J. Environ. Sci. Tech., 4 (4): 489-496, Autumn 2007
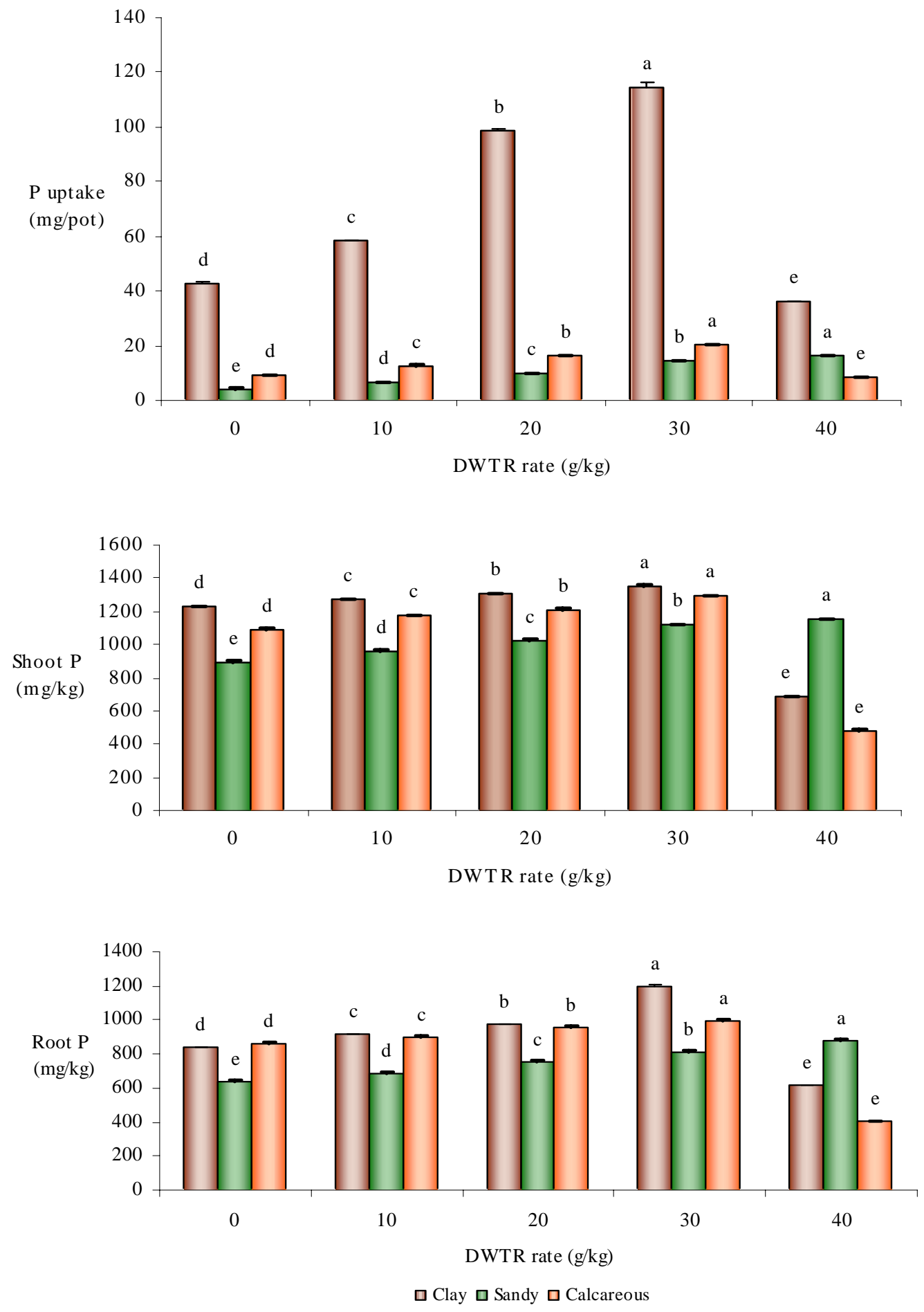

Fig. 1: Phosphorus concentrations and uptake of corn plants grown in the three DWTR-treated soils. Error bars on all figures represent the standard error of the mean. Where no error bars are present, the standard error was too small to be represented as the scale of the diagram. Letters above bars (a, b, c, d and e) indicate that means with the same letter are not significantly different at the 0.05 probability level according to the LSD 


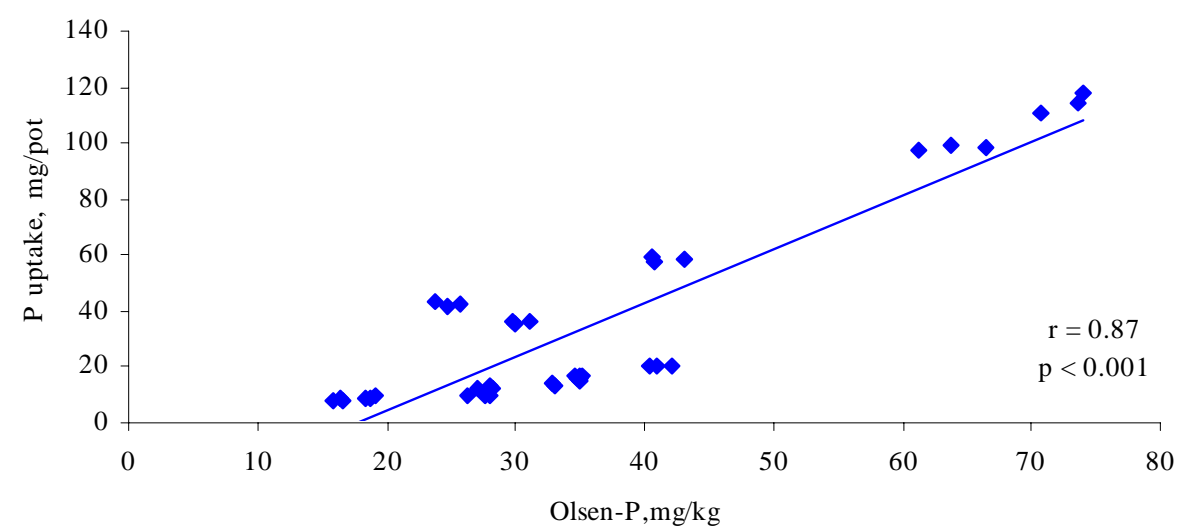

Fig. 2: Relationship between available phosphorus and phosphorus uptake of corn plants grown in DWTR-treated soils

Table 4: Olsen-phosphorus concentrations for three soils influenced by DWTR rates

\begin{tabular}{|c|c|c|}
\hline \multirow{2}{*}{ DWTR rate } & \multicolumn{2}{|c|}{ Olsen phosphorus concentration } \\
\hline & Before cultivation & After harvest \\
\hline $\mathrm{g} / \mathrm{kg}$ & \multicolumn{2}{|c|}{$\mathrm{mg} / \mathrm{kg}$} \\
\hline \multicolumn{3}{|l|}{ Clay } \\
\hline 0 & 24.75 & 3.66 \\
\hline 10 & 41.42 & 13.00 \\
\hline 20 & 63.83 & 14.61 \\
\hline 30 & 72.75 & 14.99 \\
\hline 40 & 30.28 & 11.76 \\
\hline Mean & 46.61 & 11.60 \\
\hline \multirow[t]{2}{*}{$\mathrm{LSD}_{0.05}$} & 3.01 & \multirow{2}{*}{1.15} \\
\hline & Sandy & \\
\hline 0 & 2.89 & 0.81 \\
\hline 10 & 8.97 & 5.71 \\
\hline 20 & 27.27 & 23.13 \\
\hline 30 & 33.63 & 27.27 \\
\hline 40 & 34.80 & 24.47 \\
\hline Mean & 21.51 & 16.28 \\
\hline \multirow[t]{2}{*}{$\operatorname{LSD}_{0.05}$} & 1.27 & 1.05 \\
\hline & \multicolumn{2}{|l|}{ Calcareous } \\
\hline 0 & 18.70 & 14.60 \\
\hline 10 & 27.77 & 22.00 \\
\hline 20 & 35.04 & 26.93 \\
\hline 30 & 41.18 & 31.03 \\
\hline 40 & 16.33 & 11.98 \\
\hline Mean & 27.80 & 21.31 \\
\hline \multirow[t]{2}{*}{$\operatorname{LSD}_{0.05}$} & 1.03 & 0.97 \\
\hline & \multicolumn{2}{|c|}{ F-test } \\
\hline $\begin{array}{l}\text { Analysis of } \\
\text { variance }\end{array}$ & Olsen-PBC & Olsen-PAH \\
\hline Soil & $* * *$ & $* * *$ \\
\hline Rate & $* * *$ & $* * *$ \\
\hline Rate X soil & $* * *$ & $* * *$ \\
\hline
\end{tabular}

*** Significant at the 0.001 probability level. Olsen-PBC : Olsenphosphorus before cultivation; Olsen-PAF: Olsen-phosphorus after harvest
However, application of DWTR at a rate of $40 \mathrm{~g} / \mathrm{kg}$ to clay and calcareous soils significantly decreased available phosphorus concentrations. This is expected because $\mathrm{Al}$ compounds in Al-DWTR tend to reduce plant available phosphorus and to create phosphorus deficiency at the higher rates of DWTR, through a combination of specific ion adsorption and precipitation reactions on $\mathrm{Al}$ hydroxides in the form precipitated aluminum phosphate (Gallimore, et al., 1999; Makris and Harris, 2005).

\section{DISCUSSION AND CONCLUSION}

Managing DWTR applications to maintain soil phosphorus at agronomic and environmentally acceptable levels should consider the influence of DWTR application rates on extractable phosphorus. Plant yields as well as availability of the phosphorus in three different alkaline soils amended with different rates of DWTR were examined. The results show that low application rates $(30 \mathrm{~g} / \mathrm{kg})$ of DWTR produced greater plant dry matter yield without creating phosphorus deficiency and Al phytotoxicity. The increase in dry matter production may be due to an increase in soil water holding capacity with DWTR additions, as well as its high content of organic matter, available phosphorus and CEC (Ippolito, et al., 1999; Sultani, et al., 2007). Skene, et al., (1995) indicated that the physical properties of alum (i.e. water holding capacity and drainage characteristics) are probably more important than inherent nutrient levels. The significant differences in dry matter yield of corn growth in the studied soils are consistent with significant differences in water holding capacity of the three soils (Tables 2 and 3). The dry matter results are similar to the results of Heil and Barbarick, (1989) they observed 
an increase in dry matter yield of lettuce with DWTR application. At DWTR application rate of $40 \mathrm{~g} / \mathrm{kg}$, the dry matter production of corn in calcareous and clay soils were significantly decreased as a result of decreasing plants phosphorus uptake (Table 2). Bugbee and Frink (1985) reported a decrease in plant growth with increasing amount of alum-sludge added due to a decrease in plant tissue total phosphorus concentrations. Application of 10, 20 and $30 \mathrm{~g} / \mathrm{kg}$ DWTR significantly increased plant phosphorus concentrations in the plant materials (shoots and roots) taken from the three soils. Further increase in DWTR application rate has resulted in negative significant impact on plants $\mathrm{P}$ concentration, especially in clay and calcareous soils, but in sandy soils the increase in phosphorus concentration extended to $40 \mathrm{~g} / \mathrm{kg}$ DWTR rate. The reduction in available phosphorus concentration at the higher rates of DWTR could be attributed to formation of precipitated aluminum phosphate (Ippolito, et al., 1999; Sims and Luka-Mc Cafferty, 2002). Because sorption capacity of sandy soil is small, increasing available phosphorus concentration at a higher rate of DWTR is expected (Table 4). Peters and Basta (1996) concluded that the addition of DWTR reduced excessive amounts of bioavailable phosphorus, and by increasing the application rate, the amount of bioavailable phosphorus continued to decrease. Land application of high rates of DWTR has induced similar P deficiency in other studies (Rengasamy, et al., 1980; Bugbee and Frink, 1985; Chakrabarty, 2007). Gandhaupudi, et al., (2005) indicated that addition of DWTR to poultry litter reduced the soluble phosphorus lost to aqueous streams. Moore, et al., (2000) observed a $73 \%$ reduction in soluble phosphorus concentrations in runoff from pastures fertilized with DWTR-treated poultry litter compared to pastures receiving untreated poultry litter. Based on our study and previous studies, the application of phosphorus fertilizer or biosolids containing high $\mathrm{P}$ concentration may overcome phosphorus limitations brought about by DWTR application, but this concept needs more research and experiments. The relationship between a soil testing extracting and plant nutrient uptake should be an important parameter in the selection of a soil testing method (Stiffens, 1994). Combined analyses of all soils and DWTR rates studied clearly indicated significant relationship between available phosphorus concentration and phosphorus uptake $(\mathrm{r}=0.87, \mathrm{P}<$ 0.001 , Fig. 2). In conclusion, low application rates of
DWTR produced greater plant dry matter yield associated with the three studied soils without creating a deficiency of phosphorus. Apparently, phosphorus fixation was minimal at these rates. The low application rates of the DWTR used in this study could be safely applied to the studied soils. Based on our experiment results, the rate of $30 \mathrm{~g} / \mathrm{kg}$ is considered the best application rate of DWTR because of its positive effects on plant dry matter. However, additional studies are necessary to confirm these results under field conditions.

\section{REFERENCES}

Abdel-Kader, F.H.; Abdel-Hamid, N.E.,(1974). Comparative microbiology of some soil types of lower Egypt.Geoderma, 12, 245-262.

Barroin, G., (1999). Lutte contre le dys fonctionnement des plans d,eaulies aux exce's de nutriment. Agence de l'Eau, Etude interagence., 62, 214-219.

Bloom, P.R.; Weave, R.; Mcbride, M.B., (1978). The spectrophotometric and flurometric determination of aluminum with 8-hydroxyquinoline and butyl acetate extraction. Soil Sci. Soc. Am. J., 42, 712-716.

Bremner, J.M.; Mulvaney, C.S., (1982). Nitrogen-total. In Methods of soil analysis, eds., Page ,A.L.; Miller, R.H. ; Keeney, D.R. American Soc. of Agronomy, Madison, Wisconsin, USA. 595-623.

Bugbee, G.J.; Frink, C.R., (1985). Alum sludge as a Soil amendment: effects on soil properties and plants growth. Connecticut, Conn. Agric. Exp. Stn. Bull. \# 827.

Chakrabarty, D., (2007). Comparative utilization of phosphorus from sedimentary and igneous phosphate rock by major biotic components of aquatic ecosystem. Int. J. Environ. Sci. Tech., 4 (1), 43-48.

Day, P.R., (1965). Particle fraction and particle size analysis .In Methods of soil analysis, Black, A.C; Evans, D.D.; Ensminger, L.E.; White, J.L.; Clark, F.E. (Eds.) American Soc. of Agronomy, Madison, Wisconsin, USA. 545-566.

Elliott, H.A.; Singer, L.M., (1988). Effect of water treatment sludge on growth and elemental composition of tomato shoots. Commum. Soil Sci. Plant Anal., 19, 345-354.

Francko, D.A.; Heath, R.T., (1981). Aluminum sulphate treatment: short-term effect on complex phosphorus compounds in a eutrophic lake. Hydrobiologia., 78, 25-128.

Gallimore, L.E.; Basta, N.T.; Storm, D.E.; Payton, M.E.; Hutnke, R.H; Smolen, M.D., (1999). Water treatment residuals to reduce nutrients in surface runoff from agricultural land. J. Environ. Qual., 28, 1474-1478.

Gandhaupudi, S.K.; Coyne, M.S.; Angelo, E.M.; Matocha, C., (2005). Potential nitrification in alum-treated soil slurries amended with poultry manure. Biores. Tech., 97, 664670 .

Heil, D.N.; Barbarick, K.A., (1989). Water treatment sludge influence on the growth of sorgum-sudangrass. J. Environ. Qual., 18, 292-298.

Ippolito, J.A.; Barbarick, K.A.; Rendte, E.F., (1999). Coapplication of water treatment residuals and biosolids on two range grasses. J. Environ. Qual., 28,1644-1650. 
Jiang, J.Q.; Graham, N.J.D., (1998). Pre-polymerized inorganic coagulant and phosphorus removal by coagulation-a review. Water S.A., 243,237-244.

Jones, J.B., (2001). Laboratory guide of conducting soil tests and plant analysis. CRC Press. New York, Washington, D.C.USA.

Klapper, H., (1991). Control of eutrophication in inland waters. Prentice Hall, Chichester.

Knudsen, D.; Peterson, G.A.,(1982). Lithium, sodium, and potassium . In Methods of soil analysis, Page, A.L.; Miller, R.H.; Keeney, D.R., (Eds). American Soc. of Agronomy, Madison, Wisconsin, USA. 225.

Makris, K.C.; Harris, W.G., (2005). Time dependency and irreversibility of water desorption by drinking water treatment residuals: implication for sorption mechanisms. J. Colloid Interface Sci., 294, 151-154.

Moore, P.A; Daniel, T.C.; Edwards, D.R., (2000). Reducing phosphorus runoff and inhibiting ammonia loss from poultry manure with aluminum sulfate. J. Environ. Qual. 29, 37-49.

Mortell, A.E.; Motekaitis, R.J., (1989). Coordination chemistry and speciation of $\mathrm{Al}$ (III) in aqueous solution. In Environmental chemistry and toxicology of aluminum, Lewis, T.E., (Ed.), Lewis Publishers, Chelsea, 3-17.

Nelson, D.W.; Sommers, L.E., (1982). Total carbon, organic carbon and organic. In Methods of soil analysis, Page, A.L.; Miller, R.H.; Keeney, D.R., (Eds.), American Soc. of Agronomy, Madison, Wisconsin, USA. 539-549.

Nelson, R.E., (1982). Carbonate and gypsum. In Methods of soil analysis, Page, A.L.; Miller, R.H.; Keeney, D.R., (Eds.), American Soc. of Agronomy, Madison, Wisconsin, USA. 181-197.

Olsen, S.R.; Sommers, L.E., (1982). Phosphorus. In Methods of soil analysis, Page, A.L.; Miller, R.H.; Keeney, D.R., (Eds.), American Soc. of Agronomy, Madison, Wisconsin, USA. 403-427.
Peters, J.M.; Basta, N.T., (1996). Reduction of excessive bioavailable phosphorus in soils by using municipal and industrial wastes. J. Environ. Qual., 25, 1236-1241.

Rengasamy, P.; Oades, J.M.; Hancock, T.W., (1980). Improvement of soil structure and plant growth by addition of alum sludge. Commun. Soil Sci. Plant Anal., 11, 533-545.

Rhoades, J.D., (1982). Cation exchange capacity. In Methods of soil analysis, Page, A.L.; Miller, R.H.; Keeney, D.R., (Eds.), American Soc. of Agronomy, Madison, Wisconsin, USA. 149-157.

Richard, L.A., (1954). Diagnosis and improvement of saline and alkaline soils. Handbook 60.US. Government Printing Office, Washington, D.C.

Ross, G.J.; Wang, C., (1993). Acid ammonium oxalate method. In Sampling and methods of analysis, ed, Carter M.R. Lewis Pub.,Ann Arbor, MI.

SAS Institute., (1994). SAS/STAT User's guide. Version $6.4^{\text {th }}$ ed. SAS Inst., Cary, N.C.

Sims, J.T.; Luka-Mc-Cafferty, N.J., (2002). On farm evaluation of aluminum sulphate (alum) as a poultry litter amendment: effect on litter properties. J. Environ. Qual., 31, 20662073.

Skene, T.M.; Oades, J.M.; Kilmore, G., (1995). Water treatment sludge: a potential plant growth medium. Soil Use and Mana., 11, 29-33.

Stiffens, D., (1994). Phosphorus release kinetics and extractable phosphorus after long-term fertilization. Soil Sci. Soc. Am. J., 58, 1702-1708.

Sultani, M.I.; Gill, M.A.; Anwar, M.M.; Athar, M., (2007). Evaluation of soil physical properties as influenced by various green manuring legumes and phosphorus fertilization under rainfed conditions, Int. J. Environ. Sci. Tech., 4 (1), 109-118.

Ure, A.M., (1995). Methods of soil analysis for heavy metals in Soils. In Heavy Metals in Soils ,ed, Alloway B.J. $2^{\text {nd. }}$ Ed. Blackie Academic and Professional, London. 58-95.

\section{AUTHOR (S) BIOSKETCHES}

Mahdy, A. M., Department of Soil and Water, College of Agriculture (Elshatby), Alexandria University, Alexandria, 21545, Egypt. Email: amahdy73@yahoo.com

Elkhatib, E. A., Department of Soil and Water, College of Agriculture (Elshatby), Alexandria University, Alexandria, 21545, Egypt. Email: selkhatib1@yahoo.com

Fathi, N. O., Salinity and Alkalinity Soils Research Laboratory, Ministry of Agriculture, Cairo, Egypt. Email: nieven74@yahoo.com

This article should be referenced as follows:

Mahdy, A.M.; Elkhatib, E.A.; Fathi, N.O., (2007). Drinking water treatment residuals as an amendment to alkaline soils: effects on the growth of corn and phosphorus extractability. Int. J. Environ. Sci. Tech., 4 (4), 489-496. 